University of Nebraska - Lincoln

DigitalCommons@University of Nebraska - Lincoln

\title{
Chemical Optimization of Protein Extraction from Sweet Potato (Ipomoea batatas) Peel
}

\author{
Katherine P. Maloney \\ North Carolina State University at Raleigh \\ Van-Den Truong \\ North Carolina State University at Raleigh, den_truong@ncsu.edu \\ Jonathan C. Allen \\ North Carolina State University at Raleigh, Jon_Allen@ncsu.edu
}

Follow this and additional works at: https://digitalcommons.unl.edu/usdaarsfacpub

\footnotetext{
Maloney, Katherine P.; Truong, Van-Den; and Allen, Jonathan C., "Chemical Optimization of Protein Extraction from Sweet Potato (Ipomoea batatas) Peel" (2012). Publications from USDA-ARS / UNL Faculty. 1112.

https://digitalcommons.unl.edu/usdaarsfacpub/1112
}

This Article is brought to you for free and open access by the U.S. Department of Agriculture: Agricultural Research Service, Lincoln, Nebraska at DigitalCommons@University of Nebraska - Lincoln. It has been accepted for inclusion in Publications from USDA-ARS / UNL Faculty by an authorized administrator of DigitalCommons@University of Nebraska - Lincoln. 


\title{
Chemical Optimization of Protein Extraction from Sweet Potato (Ipomoea batatas) Peel
}

\author{
Katherine P. Maloney, Van-Den Truong, and Jonathan C. Allen
}

\begin{abstract}
Proteins isolated from sweet potatoes (Ipomoea batatas) have been shown to possess antidiabetic, antioxidant, and antiproliferative properties. The objective of this study was to chemically optimize a process for extracting proteins from sweet potato peel. The extraction procedure involved mixing peel with saline solvent to dissolve proteins and then precipitating with $\mathrm{CaCl}_{2}$. Quadratic and segmented models were used to determine the optimum $\mathrm{NaCl}$ concentration and peel to solvent ratio to maximize protein solubility while minimizing solvent usage. A segmented model was also used to optimize the concentration of $\mathrm{CaCl}_{2}$ used for precipitation. The highest yield was obtained by mixing blanched peelings with $59.7 \mathrm{~mL}$ of $0.025 \mathrm{mM} \mathrm{NaCl}$ per g peel and then precipitating with $6.8 \mathrm{mM} \mathrm{CaCl}_{2}$. The results of this study show that potentially valuable proteins can be extracted from peel generated during processing of sweet potatoes and industrial costs can be minimized by using these optimum conditions.
\end{abstract}

Keywords: extraction, model, optimization, protein, sweet potato

Practical Application: Potentially valuable proteins can be extracted from sweet potato peel, a waste product of sweet potato processing.

\section{Introduction}

Sweet potato (Ipomoea batatas) proteins possess many properties beneficial to human health. Caiapo Potato powder, a protein extract from a white-skinned sweet potato cultivar, lowered fasting blood glucose levels and increased insulin sensitivity in type II diabetics (Ludvik and others 2003, 2004, 2008; Kusano and others 2005). A $22 \mathrm{kDa}$ acidic glycoprotein (Kusano and others 2001) and a $126.8 \mathrm{kDa}$ arabinogalactan-protein (Ozaki and others 2010) have been proposed as the active components of Caiapo Potato powder. Sweet potato trypsin inhibitor proteins (TIP) possess antioxidant properties against several reactive oxidizing species (Hou and others 2001; Huang and others 2007b). Feeding sweet potato TIP to mice increased serum superoxide dismutase, catalase, and glutathione peroxidase activity (Huang and others 2008). Sweet potato TIP also showed antiproliferative properties, inhibiting the growth of NB4 promyeolcytic leukemia cells (Huang and others 2007a). In addition to these nutritional benefits, sweet potato proteins have high water solubility and stabilize emulsions over a wide $\mathrm{pH}$ range ( $\mathrm{Mu}$ and others 2009).

Various solvents have been used to extract proteins from root and tuber crops. Homogenization with $0.02 \mathrm{M}$ sodium phosphate buffer containing $0.3 \mathrm{M} \mathrm{NaCl}$ maximized extraction of alphaamylase inhibitory proteins from taro sweet potatoes (Rekha and others 1997, 1999). Shivaraj and others (1979) used distilled wa-

MS 20120008 Submitted 1/2/2012, Accepted 6/11/2012. Authors Maloney, Truong, and Allen are with the Dept. of Food, Bioprocessing, and Nutrition Sciences, North Carolina State Univ., Box 7624, Raleigh, NC 27695, U.S.A. Author Truong is also with the USDA-ARS Food Science Research Unit, North Carolina State Univ., Box 7624, Raleigh, NC 27695, U.S.A. Direct inquiries to author Allen (E-mail: Jon_Allen@ncsu.edu). ter to extract alpha-amylase inhibitory proteins from sweet potatoes, and Purcell and others (1978) and Walter and Catignani (1981) also started their protein extractions by blending with water. Kusano and others (2001) and Ozaki and others (2010) also began their process to isolate the protein responsible for the antidiabetic properties of sweet potatoes by mixing with distilled water. Few researchers have compared solvents. Previous research in our laboratory (Peters 2007) found greater protein yield when sweet potato proteins were extracted in a $3 \mathrm{M} \mathrm{NaCl}$ and $50 \mathrm{mM} \mathrm{NaHPO}_{4}$ buffer than extraction in distilled water. Subsequently we have determined the phosphate is not essential for the highest protein yield.

Various techniques can precipitate the extracted sweet potato proteins from solution. Purcell and others (1978) employed both heat treatment and $0.5 \% \mathrm{CaCl}_{2}$ while Walter and Catignani (1981) used heat treatment and $0.1 \% \mathrm{CaCl}_{2}$ to precipitate sweet potato proteins. Peters (2007) found equivalent efficiency of precipitation of sweet potato proteins from solution with $\mathrm{CaCl}_{2}$ and ammonium sulfate but did not determine optimum $\mathrm{CaCl}_{2}$ concentration to precipitate the maximum amount of protein. Other techniques available to precipitate proteins include heat denaturation and isoelectric precipitation with acids, but both of these are likely to destroy bioactive functions of protein.

Sweet potato peel generated during the processing of sweet potatoes into puree currently has little market value, but is a good source for protein extraction. The objective of this research was to chemically optimize the process for extracting proteins from sweet potato peel. Proteins were dissolved by mixing peel with saline solvent and then precipitated with $\mathrm{CaCl}_{2}$. Response surface methodology was a less effective optimization technique than a linear segmented model of the solvent to peel ratio data. A quadratic model was used to determine the optimum $\mathrm{NaCl}$ concentration to maximize protein solubility. A linear segmented model was also 
used to optimize the concentration of $\mathrm{CaCl}_{2}$ used for precipitation. After the optimum conditions for extraction were determined, sodium dodecyl sulfate-polyacrylamide gel electrophoresis (SDS-PAGE) was used to visualize the proteins present in the extract and compare the extract to Caiapo Potato powder.

\section{Materials and Methods}

\section{Chemicals and materials}

Sodium chloride and calcium chloride were obtained from Sigma-Aldrich (St. Louis, Mo., U.S.A.). Sweet potato peel was obtained from a local processing plant (Yamco, LLC, Snow Hill, N.C., U.S.A.). Peel was from a mixture of orange-fleshed cultivars including Beauregard, Jewel, and Covington. Peel was obtained from 2 different points along the processing line, the initial peeling of the sweet potatoes before any further processing, called "primary peelings" and a secondary peeling after blanching of the sweet potatoes, called "secondary peelings." Upon receipt, the primary and secondary peelings were freeze dried and stored at $-20{ }^{\circ} \mathrm{C}$. Caiapo Potato powder was obtained from Fuji-Sangyo Co., Ltd. (Kagawa, Japan).

\section{Protein extraction}

Proteins were extracted by mixing primary peelings or secondary peelings with saline solvent, centrifuging the mixture at $1000 \times g$ for $5 \mathrm{~min}$, and then vacuum filtering the supernatant through Whatman 4 filter paper. Proteins were precipitated from the supernatant by adding calcium chloride, vortexing for $10 \mathrm{~s}$, incubating for $15 \mathrm{~min}$ at either 25,65 , or $95^{\circ} \mathrm{C}$, and then centrifuging at $1000 \times g$ for $10 \mathrm{~min}$ to obtain a protein pellet. The quantity of protein precipitated was calculated by subtracting protein in the supernatant after precipitation from protein in the supernatant before precipitation.

\section{Protein and calcium analysis}

Protein in liquid samples was determined using Bradford assay (Thermo Fisher Scientific, Rockford, Ill., U.S.A.). Protein in solid samples was determined using the Kjeldahl method with 6.25 as the conversion factor. Calcium in the precipitate was measured by atomic absorption and the iodine-binding method was used to determine if starch was present in the precipitate.

\section{Determining optimum conditions for protein extraction}

The results on protein extraction as affected by concentration of $\mathrm{NaCl}$ were fit to a linear segmented model using SAS 2011 (SAS, Cary, N.C., U.S.A.). The Eq. (1) was

$$
\begin{array}{lll}
y=m_{1} * x+b_{1} & \text { if } & x<\theta \\
y=m_{2} * \theta+b_{2} & \text { if } & x \geq \theta
\end{array}
$$

where $y=$ protein extracted $(\mathrm{mg}), m=$ slope, $x=$ solvent $(\mathrm{mL})$, $b=\mathrm{y}$-intercept, and $\theta=$ join point. The values obtained for protein extracted and join point were then fit to a quadratic model using SAS 2011 (SAS). The Eq. (2) was

$$
y=\beta_{1}^{*} x^{2}+\beta_{2}^{*} x+\beta_{3}
$$

where $y=$ protein extracted (mg) per g peel (dry weight) or join point and $x=\log \mathrm{NaCl}(\mathrm{M})$. The $\mathrm{NaCl}$ concentration for maximum protein extraction was determined from the model with $y=$ protein extracted (mg) per g peel (dry weight) and then join point at this $\mathrm{NaCl}$ concentration was determined from the model with $y=$ join point.
Determining optimum conditions for protein precipitation

The percentage protein precipitated based on the initial protein in solution at each level of $\mathrm{CaCl}_{2}$ addition was fit to a linear segmented model with SAS 2011 (SAS). The Eq. (3) was

$$
\begin{array}{lll}
y=m_{1}{ }^{*} x+b_{1} & \text { if } & x<\theta \\
y=m_{2}{ }^{*} \theta+b_{2} & \text { if } & x \geq \theta
\end{array}
$$

where $y=$ protein precipitated $(\%), m=$ slope, $x=\mathrm{CaCl}_{2}(\mathrm{mM})$, $b=\mathrm{y}$-intercept, and $\theta=$ join point. Optimum level of $\mathrm{CaCl}_{2}$ addition was the join point since further addition beyond the join point would not increase $\%$ protein precipitated.

\section{Gel electrophoresis}

Reducing SDS-PAGE was performed to compare the peel protein extract to Caiapo Potato powder. Samples and BenchMark prestained protein ladder (Invitrogen, Carlsbad, Calif., U.S.A.) were run on a $15 \%$ Tris-HCl Ready Gel (Bio-Rad Laboratories, Hercules, Calif., U.S.A.) at a constant voltage of 200 V. One gel was stained with Imperial protein stain (Thermo Fisher Scientific, Rockford, Ill., U.S.A.) to view the total protein banding pattern and one gel was stained with Glycoprotein Staining Kit (Thermo Fisher Scientific) to view the glycoprotein banding pattern.

\section{Results and Discussion}

\section{Protein extraction}

The method chosen to optimize the extraction process involved fitting data to linear segmented and quadratic models despite the recent popularity of the response surface method to optimize protein extraction processes (Quanhong and Caili 2005; Kanu and others 2007; Eromosele and others 2008; Guan and Yao 2008; Peričin and others 2008; Arifin and others 2009; Nurdiyana and Mazlina 2009). The response surface method is often chosen for optimization experiments because of the ability to obtain a vast amount of information from a small number of experiments and the ability to determine how the interaction of variables affects the response. However, a major limitation of the response surface method is that the data must be fit to a second order polynomial (Baş and Boyac1 2007). In this research, the fit limitation outweighed the advantages of using the response surface method. A second order polynomial fit for $\mathrm{NaCl}$ concentration compared to protein extracted could be obtained by log transformation; however, solvent to solute ratio could not be adequately fit to a second order polynomial. At a certain point, protein extracted remained constant despite continued addition of solvent, and determination of this point was important because it represented the most efficient solvent to solute ratio, that is, protein extraction was maximized while solvent usage, and thus cost, was minimized.

The results for proteins extracted over different solvent to peel ratios were fit to a linear segmented model for each of the $\mathrm{NaCl}$ concentrations tested. Figure 1 and 2 show the models fit to the data obtained for primary and secondary peelings mixed with $0.001,0.01,0.1$, and $1 \mathrm{mM} \mathrm{NaCl}$, respectively. A point was seen for each solvent in which increasing solvent volume no longer increased protein extracted. This point was termed the join point because it is the point where the 2 lines of the segmented model cross. The join point in this research represents the optimum ratio of solvent to peel and addition of solvent beyond this point does not increase yield but adds to cost.

In order to determine the true optimum $\mathrm{NaCl}$ concentration, a quadratic model was fit to protein extracted compared to log 
$[\mathrm{NaCl}]$. A salting in and salting out effect was observed for both peel and blanched peel mixed with saline solvent. Figure 3 shows the quadratic model fit to $\log [\mathrm{NaCl}]$ compared to protein extracted for primary peelings and Figure 4 shows the quadratic model fit to $\log [\mathrm{NaCl}]$ compared to protein for secondary peelings. The optimum $\mathrm{NaCl}$ concentration was $\log [\mathrm{NaCl}]=-4.7$

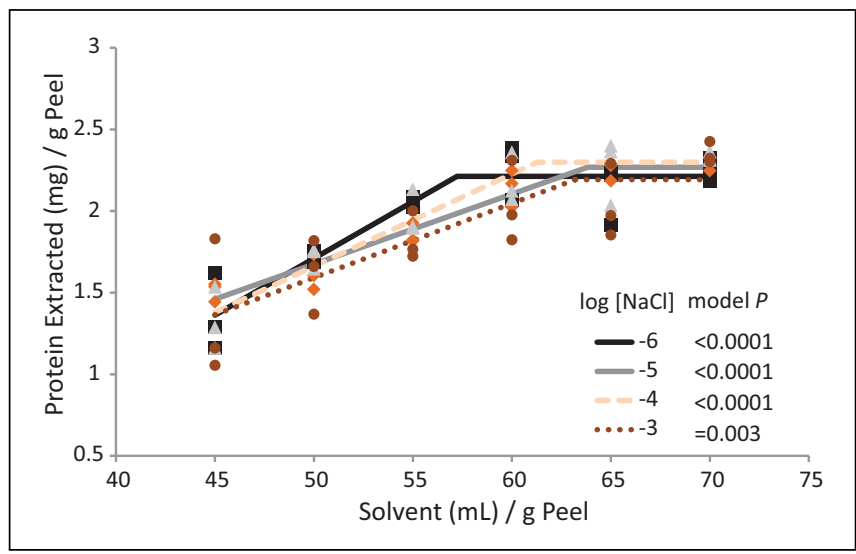

Figure 1-Linear segmented models fit to extraction data for primary peelings.

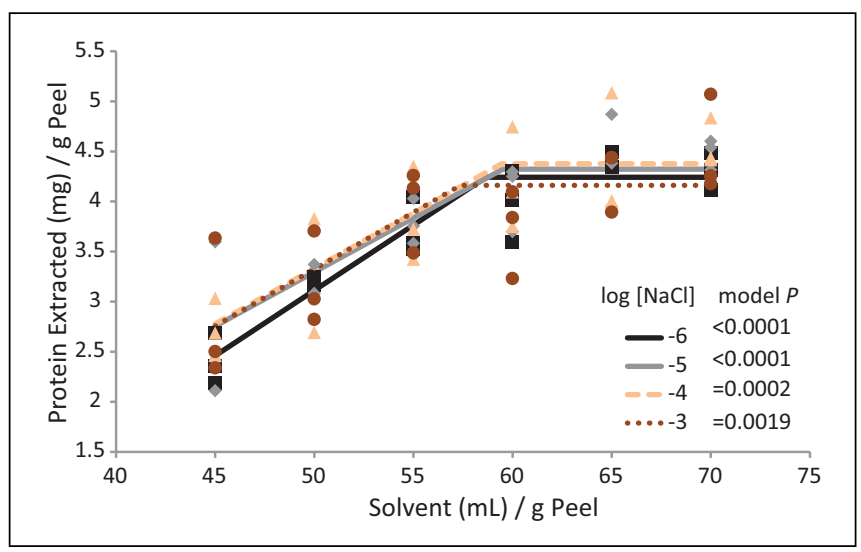

Figure 2-Linear segmented models fit to extraction data for secondary peelings.

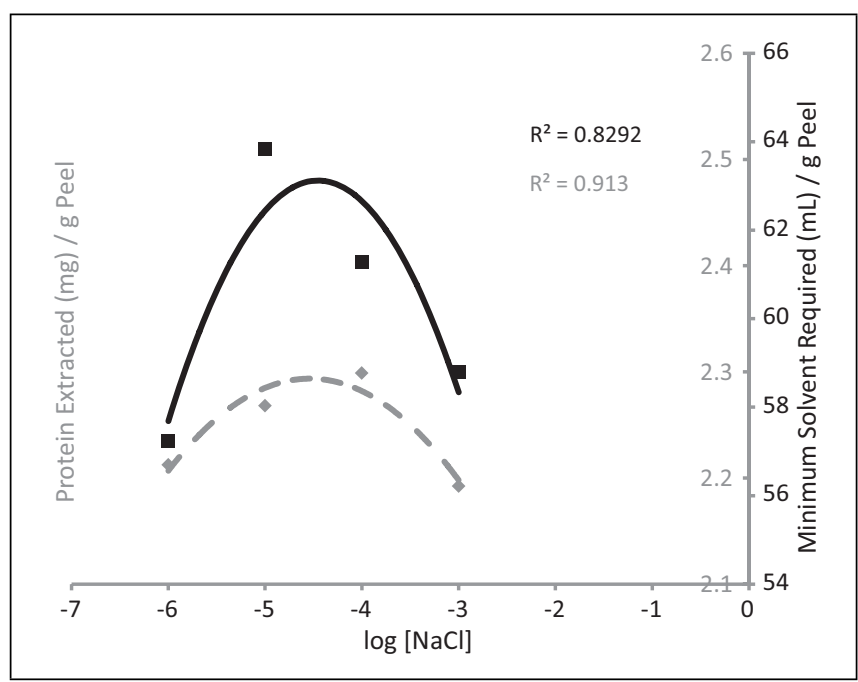

Figure 3-Optimizing $\mathrm{NaCl}$ concentration and solvent to peel ratio for protein extraction from primary peelings using quadratic models. for primary peelings and $\log [\mathrm{NaCl}]=-4.6$ for secondary peelings. A quadratic model was also fit to join point compared to log $[\mathrm{NaCl}]$ in order to find the minimum solvent required to extract maximum protein. Figure 3 and 4 show the quadratic models fit to $\log [\mathrm{NaCl}]$ compared to join point for primary and secondary peelings, respectively. Once the optimum $\mathrm{NaCl}$ concentration had been determined, this value was substituted into the join point quadratic equation. The predicted join point for primary peelings at $\log [\mathrm{NaCl}]=-4.7$ was $63.0 \mathrm{~mL}$ solvent per g peel (dry weight) and the predicted join point for secondary peelings at $\log [\mathrm{NaCl}]=$ -4.6 was $59.7 \mathrm{~mL}$ solvent per g blanched peel (dry weight). A trial was run using the optimum conditions predicted by the models, $63.0 \mathrm{~mL}$ of $0.02 \mathrm{mM} \mathrm{NaCl}$ per g primary peelings and $59.7 \mathrm{~mL}$ of $0.025 \mathrm{mM} \mathrm{NaCl}$ per g secondary peelings. The predicted protein extracted from primary peelings was $2.30 \mathrm{mg}$ per g peel (dry weight) and the experimental protein extracted was $2.36 \pm 0.26 \mathrm{mg}$ per $\mathrm{g}$ peel (dry weight). The predicted protein extracted from secondary peelings was $4.37 \mathrm{mg}$ per g peel (dry weight) and the experimental protein extracted was $4.35 \pm 0.06$ mg per g peel (dry weight).

\section{Protein precipitation}

Optimizing concentration of $\mathrm{CaCl}_{2}$ for protein precipitation also used a linear segmented model. The join point represents the concentration above which additional $\mathrm{CaCl}_{2}$ would no longer increase yield but would increase cost. The effect of temperature on peel protein precipitation was also investigated because some pulp proteins were found by Purcell and others (1978) to precipitate at $65{ }^{\circ} \mathrm{C}$ while other proteins precipitated at $95^{\circ} \mathrm{C}$. Incubation of primary peelings solution at $95^{\circ} \mathrm{C}$ greatly reduced the concentration of $\mathrm{CaCl}_{2}$ required for maximum precipitation of protein. The join point at $95{ }^{\circ} \mathrm{C}$ was $9.3 \mathrm{mM} \mathrm{CaCl}_{2}$ where as the join point at $65^{\circ} \mathrm{C}$ was $27.6 \mathrm{mM} \mathrm{CaCl}_{2}$ and at $25^{\circ} \mathrm{C}$ was $32.7 \mathrm{mM}$ $\mathrm{CaCl}_{2}$ (Figure 5). Incubation temperature of secondary peelings solution, however, did not significantly affect concentration of $\mathrm{CaCl}_{2}$ required for maximum precipitation of protein. The join point when the model was fit to points from all temperatures was $6.8 \mathrm{mM} \mathrm{CaCl}_{2}$ (Figure 6).

Purcell and others (1978) heated sweet potato protein solution to $65^{\circ} \mathrm{C}$ and then added $0.5 \% \mathrm{CaCl}_{2}$ to precipitate the chromoplast proteins. After removing this fraction, the researchers heated

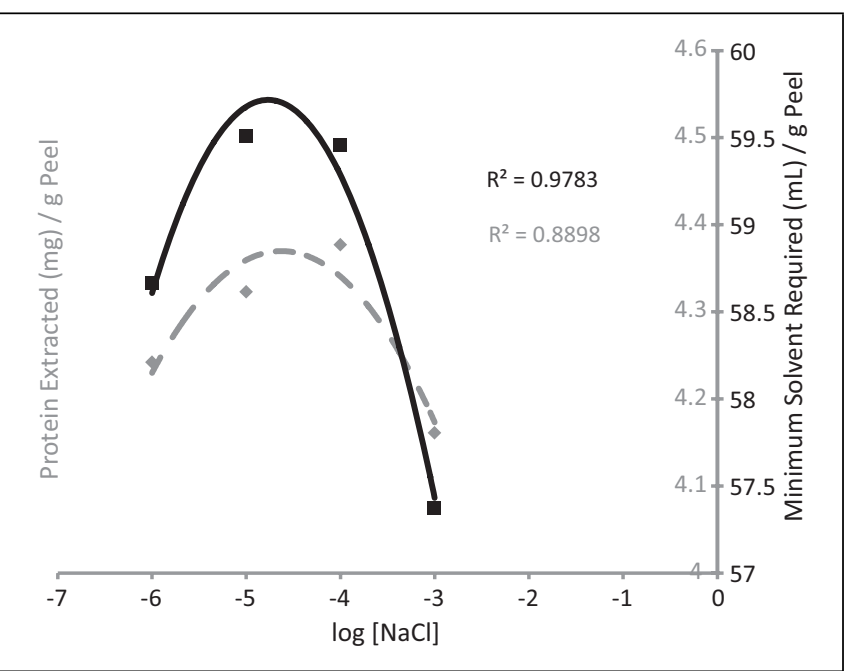

Figure 4-Optimizing $\mathrm{NaCl}$ concentration and solvent to peel ratio for protein extraction from secondary peelings using quadratic models. 
the solution to $95^{\circ} \mathrm{C}$ to coagulate and precipitate the remaining proteins. In contrast to these findings, we did not observe an increase in total proteins precipitated when the protein solution was incubated at $95{ }^{\circ} \mathrm{C}$. We did, however, observe a drastic decrease in the amount of $\mathrm{CaCl}_{2}$ required for maximum precipitation of proteins from the peel solution when temperature was increased to $95^{\circ} \mathrm{C}$.

The absence of a reduction in the amount of $\mathrm{CaCl}_{2}$ required for maximum precipitation from secondary peelings solution with incubation at $95^{\circ} \mathrm{C}$ was most likely due to heat sensitive proteins having already been denatured during blanching and being able to more readily interact with the added ions even at low temperatures. When primary peelings solution was heated to $95^{\circ} \mathrm{C}$, the amount of $\mathrm{CaCl}_{2}$ required for maximum precipitation $(9.3 \mathrm{mM})$ began to approach the amount required for maximum precipitation from blanched peel solution at any temperature $(6.8 \mathrm{mM})$, indicating that denaturation of proteins was likely responsible for the change.

Makki and others (1986) applied the procedure of Purcell and others (1978) to sweet potato peel and found that protein concentrates from sweet potato peel were lower in purity than protein concentrates from sweet potato flesh. One cultivar, Abees, yielded products containing $33.5 \%$ protein from peel compared to $76.5 \%$ protein from flesh. Another cultivar, Giza 69, yielded a product containing $53.3 \%$ protein from peel compared to $80.9 \%$ protein from flesh. We observed that $\mathrm{CaCl}_{2}$ addition beyond the point of maximum protein precipitation led to dilution of the protein by precipitation of nonprotein material, presumably soluble fiber,

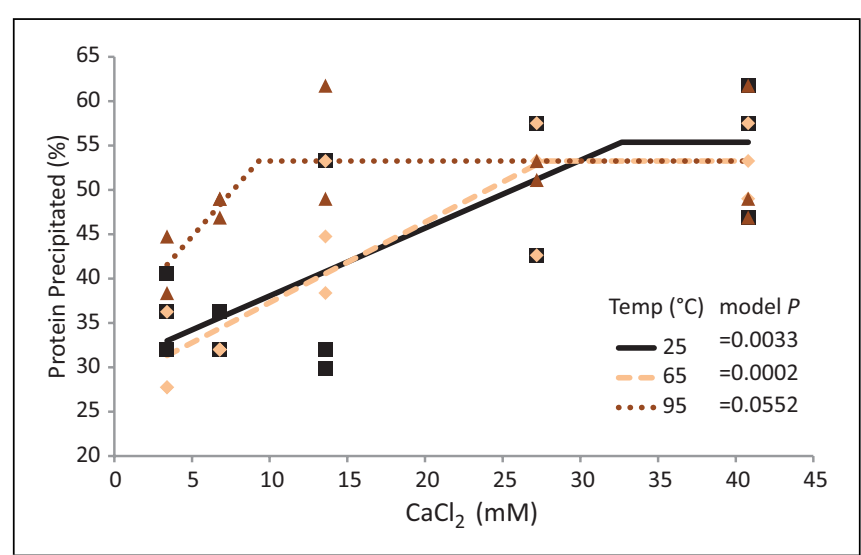

Figure 5-Linear segmented models fit to precipitation data from primary peelings.

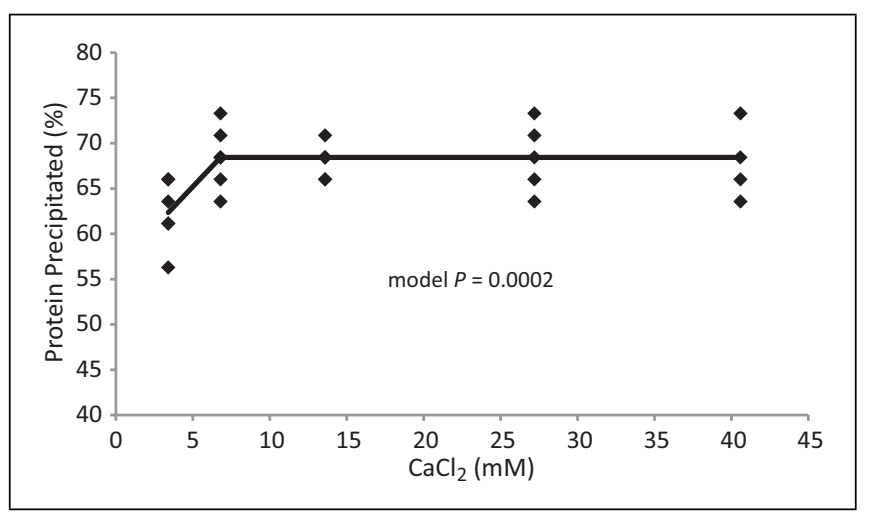

Figure 6-Linear segmented model fit to precipitation data from secondary peelings. which could explain the low protein concentration in peel extracts compared to flesh extracts.

For primary peelings, the optimum conditions for protein precipitation resulted in $14.4 \%$ of the protein in the starting material being recovered in the extract, which consisted of $4.8 \%$ protein, calculated from \% nitrogen with a conversion factor of 6.25 . In the case of secondary peelings, the optimum conditions for protein precipitation resulted in $32.0 \%$ of the protein in the starting material being recovered in the extract, which consisted of $41.3 \%$ protein, calculated from $\%$ nitrogen with a conversion factor of 6.25. The higher purity of the blanched peel extract may be due to either the lower amount of $\mathrm{CaCl}_{2}$ added for protein precipitation or the difference in composition between the blanched peel and the raw peel. The degree to which $\mathrm{CaCl}_{2}$ caused precipitation of nonprotein material, presumably soluble fiber, was more affected by higher $\mathrm{CaCl}_{2}$ concentrations than was precipitation of additional protein. Secondary peelings contained more pulp than the primary peelings which likely contributed to higher extracted protein purity. The nonprotein component in the precipitated material recovered in this study is presumed to be soluble fiber because it was low in ash and reducing sugars (data not shown).

Protein in the starting material and the final product was estimated by nitrogen analysis with a conversion factor of 6.25 . It is likely that protein was overestimated in the starting material due to the presence of nonprotein nitrogen (NPN). Up to $30 \%$ of the nitrogen in some cultivars of sweet potatoes may be NPN (Purcell and others 1978). At $107 \mathrm{~d}$ of storage, NPN in Jewel cultivar was composed mostly of amino acids; asparagine made up $61 \%$, aspartic acid $11 \%$, glutamic acid $4 \%$, serine $4 \%$, and threonine 3\% (Purcell and others 1980). It is unlikely that these small peptides or free amino acids would be precipitated with $\mathrm{CaCl}_{2}$ and thus would not be present in the final product. This would cause protein recovery to appear lower than the true value.

Secondary peelings appear to be a better starting material for protein extraction and concentration. In comparing secondary to primary peelings, more protein was present $(8.2 \%$ compared with $6.4 \%$ protein), more protein could be recovered $(32.0 \%$ compared with $14.4 \%)$, and the extract was more concentrated $(41.3 \%$ compared with $4.8 \%$ protein). The proteins extracted from secondary peelings may be of less use, however, due to possible loss of the desirable nutraceutical properties from heat treatment. Kusano and others (2000) reported that boiling in water inactivated the antidiabetic component of white-skinned sweet potato extract. Other activities of sweet potato proteins have also been reported to be heat labile. Trypsin inhibitors and amylase inhibitors in sweet potatoes can be inactivated by heat treatment, with the degree of inactivation varying based on time, temperature, and type of heat treatment (Obidairo and Akpochafo 1984; Rekha and Padmaja 2002; Kiran and Padmaja 2003; Sasi Kiran and Padmaja 2003). For the same reason, even though heating the peel solution decreased the amount of $\mathrm{CaCl}_{2}$ required for maximum protein precipitation, doing this may be undesirable because nutraceutical activities may be lost.

\section{Comparison of Caiapo Potato powder and peel extract with gel electrophoresis}

SDS-PAGE showed major protein bands present in Caiapo Potato powder at 22 and $58 \mathrm{kDa}$. These bands were also present in the peel extract; however, the intensity of the $58 \mathrm{kDa}$ band was reduced in the peel extract compared to Caiapo Potato powder (Figure 7). Despite the absence of any apparent protein bands above $58 \mathrm{kDa}$ with total protein staining, a high molecular weight 
glycoprotein was found in both the extract and Caiapo Potato powder after glycoprotein staining. A $22 \mathrm{kDa}$ glycoprotein was also present in both the peel extract and Caiapo Potato powder (Figure 8).

The proteins extracted appear to be similar, at least in molecular weight, to proteins known to have unique nutritional benefits. Glycoprotein staining (Figure 8) revealed that the $22 \mathrm{kDa}$ protein of both the extract and Caiapo Potato powder contained sugar, indicating that the active antidiabetic component of Caiapo Potato powder isolated by Kusano and others (2001) may also be present in the extract. A higher molecular weight glycoprotein was also seen in both the extract and Caiapo Potato powder, which may correspond to the active antidiabetic component isolated by Ozaki and others (2010). The protein was not detected by the Imperial protein stain; however, a very intensely colored band was seen with

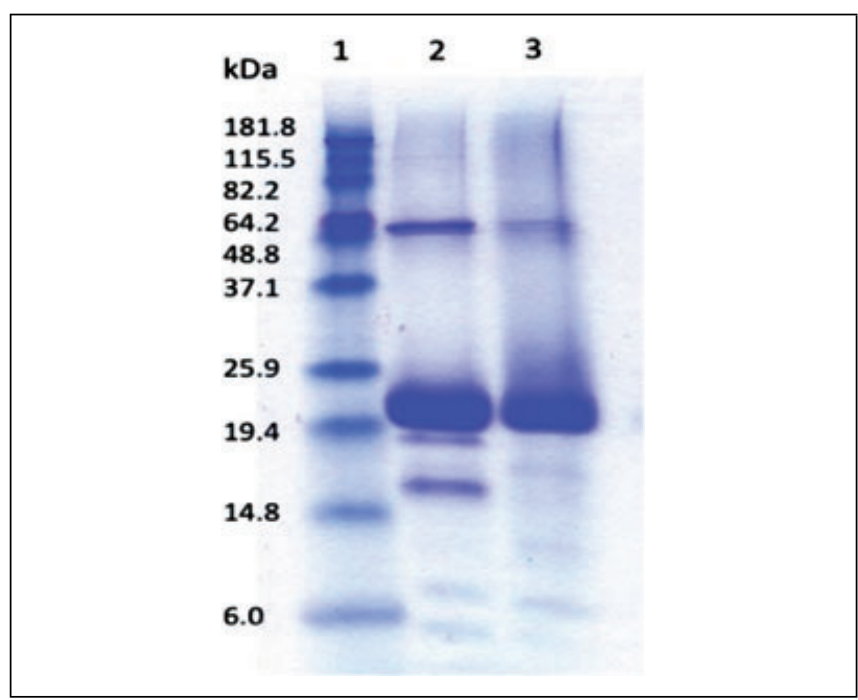

Figure 7-Comparison of Caiapo Potato powder and peel extract protein banding patterns. SDS-PAGE of protein ladder (lane 1), Caiapo Potato powder (lane 2), and peel extract (lane 3). Gel was stained with Imperial protein stain.

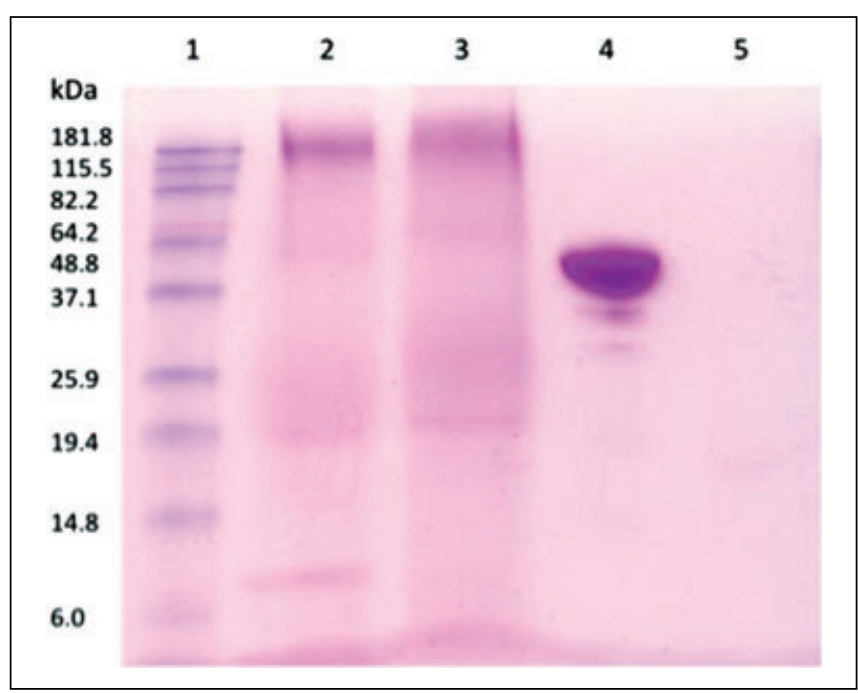

Figure 8-Comparison of Caiapo Potato powder and peel extract glycoprotein banding patterns. SDS-PAGE of protein ladder (lane 1), Caiapo Potato powder (lane 2), peel extract (lane 3 ), horseradish peroxidase positive control (lane 4), and soybean trypsin inhibitor negative control (lane 5). Gel was stained with glycoprotein staining kit. glycoprotein staining, which would fit with a product containing 95\% sugar and $5 \%$ protein, the composition reported by Ozaki and others (2010).

\section{Conclusion}

Primary industrial peeling of sweet potatoes yields a material from which concentrating the protein is difficult due to coprecipitation of nonprotein material. Much better protein concentration results can be attained using material from the secondary peeling after blanching. The optimum conditions for extracting and precipitating protein from the sweet potato peel were presented. Using the optimum conditions, $32.0 \%$ of the protein present in blanched peel was recovered in the extract, which consisted of $41.3 \%$ protein. Gel electrophoresis and glycoprotein staining suggests that the antidiabetic proteins in Caiapo Potato powder, an extract of a white-skinned sweet potato cultivar, may also be present in extracts from orange-fleshed sweet potatoes.

\section{Acknowledgments}

The authors would like to thank Dr. Jason Osborne for his help with statistical modeling. Funding was provided by the North Carolina Sweet Potato Commission and a Fellowship for KPM from the NC Biomanufacturing Training and Education Center.

\section{References}

Arifin B, Bono A, Farm YY, Ling, ALL, Fui SY. 2009. Protein extraction from palm kernel meal. J Applied Sci 9:2996-3004.

Baş D, Boyacı İH. 2007. Modeling and optimization I: usability of response surface methodology. J Food Eng 78:836-45.

Eromosele CO, Arogundade LA, Eromosele IC, Ademuyiwa O. 2008. Extractability of African yam bean (Sphenostylis stenocarpa) protein in acid, salt and alkaline aqueous media. Food Hydrocoll 22:1622-8.

Guan X, Yao H. 2008. Optimization of Viscozyme L-assisted extraction of oat bran protein using response surface methodology. Food Chem 106:345-51.

Hou WC, Chen YC, Chen HJ, Lin YH, Yang LL, Lee MH. 2001. Antioxidant activities of trypsin inhibitor, a $33 \mathrm{KDa}$ root storage protein of sweet potato (Ipomoea batatas (L.) Lam cv. Tainong 57). J Agric Food Chem 49:2978-81.

Huang GJ, Sheu MJ, Chen HJ, Chang YS, Lin YH. 2007a. Growth inhibition and induction of apoptosis in NB4 promyelocytic leukemia cells by trypsin inhibitor from sweet potato storage roots. J Agric Food Chem 55:2548-53.

Huang GJ, Sheu MJ, Chen HJ, Chang YS, Lin YH. 2007b. Inhibition of reactive nitrogen species in vitro and ex vivo by trypsin inhibitor from sweet potato 'Tainong 57 ' storage roots. J Agric Food Chem 55:6000-6.

Huang G, Chang H, Chen H, Lu T, Chang Y, Sheu M, Lin Y. 2008. Effects of trypsin inhibitor on plasma antioxidant activity and lipid levels in mice from sweet potato roots. J Sci Food Agric 88:2556-62.

Kanu PJ, Zhou HM, Kanu JB, Zhu KX, Zhu KR, Qian H. 2007. The use of response surface methodology in predicting sesame (Sesamum indicum L.) protein extractability with water and the analysis of the protein extracted for its amino acid profile. Biotechnology 6:447-55.

Kiran KS, Padmaja G. 2003. Inactivation of trypsin inhibitors in sweet potato and taro tubers during processing. Plant Foods Hum Nutr 58:153-63.

Kusano S, Abe H. 2000. Antidiabetic activity of white skinned sweet potato (Ipomoea batatas L.) in obese Zucker fatty rats. Biol Pharm Bull 23:23-6.

Kusano S, Abe H, Tamura H. 2001. Isolation of antidiabetic components from white-skinned sweet potato (Ipomoea batatas L.). Biosci Biotechnol Biochem 65:109-14.

Kusano S, Tamasu S, Nakatsugawa S. 2005. Effects of the white-skinned sweet potato (Ipomoea batatas L.) on the expression of adipocytokine in adipose tissue of genetic Type 2 diabetic mice. Food Sci Technol Res 11:369-72.

Ludvik B, Waldhausl W, Prager R, Kautzky-Willer A, Pacini G. 2003. Mode of action of Ipomoea batatas (Caiapo) in type 2 diabetic patients. Metabolism 52:875-80.

Ludvik B, Neuffer B, Pacini G. 2004. Efficacy of Ipomoea batatas (Caiapo) on diabetes control in type 2 diabetic subjects treated with diet. Diabetes Care 27:436-40.

Ludvik B, Hanefeld M, Pacini G. 2008. Improved metabolic control by Ipomoea batatas (Caiapo) is associated with increased adiponectin and decreased fibrinogen levels in type 2 diabetic subjects. Diabetes Obes Metab 10:586-92.

Makki HM, Abdel-Rahman AY, Khalil MKM, Mohamed MS. 1986. Chemical composition of Egyptian sweet potatoes. Food Chem 20:39-44.

Mu T, Tan S, Xue Y. 2009. The amino acid composition, solubility and emulsifying properties of sweet potato protein. Food Chem 112:1002-5.

Nurdiyana H, Mazlina MKS. 2009. Optimization of protein extraction from fish waste using response surface methodology. J Appl Sci 9:3121-5.

Obidairo TK, Akpochafo OM. 1984. Isolation and characterization of some proteolytic enzyme inhibitors in sweet potato (Ipomoea batatas). Enzyme Microb Technol 6:132-4

Ozaki S, Oki N, Suzuki S, Kitamura S. 2010. Structural characterization and hypoglycemic effects of arabinogalactan-protein from the tuberous cortex of the white-skinned sweet potato (Ipomoea batatas L.). J Agric Food Chem 58:11593-9.

Peričin D, Radulović L, Trivić S, Dimić E. 2008. Evaluation of solubility of pumpkin seed globulins by response surface method. J Food Eng 84:591-4. 
Peters TB. 2007. Isolation of Ipomoea batatas protein and characterization of amylase inhibitory activity. [MS thesis]. Raleigh, NC: North Carolina State Univ. 78 p. Available from: <http://www.lib.ncsu.edu/resolver/1840.16/1640>. Accessed June 4, 2012.

Purcell AE, Walter WM, Giesbrecht FG. 1978. Protein and amino acids of sweet potato (Ipomoe batatas (L.) Lam.) fractions. J Agric Food Chem 26:699-701.

Purcell AE, Walter WM, Jr, Giesbrecht FG. 1978. Changes in dry matter, protein and nonprotein nitrogen during storage of sweet potatoes. J Am Soc Hort Sci 103:190-2.

Purcell AE, Walter WM. 1980. Changes in composition of the nonprotein-nitrogen fraction of "Jewel" sweet potatoes (Ipomoea batatas (Lam.)) during storage. J Agric Food Chem 28:842-4

Quanhong L, Caili F. 2005. Application of response surface methodology for extraction optimization of germinant pumpkin seeds protein. Food Chem 92:701-6.

Rekha MR, Padmaja G, Thankamma Pillai PK. 1997. Cultivar differences in the apparent amylase inhibitory activity of taro tubers. J Root Crops 23:39-44.
Rekha MR, Padmaja G, Easwari Amma CS, Sheela MN. 1999. Cultivar differences in the alpha-amylase inhibitor activity of sweet potato and yam tubers. J Root Crops 25: 185-91.

Rekha MR, Padmaja G. 2002. Alpha-amylase inhibitor changes during processing of sweet potato and taro tubers. Plant Foods Hum Nutr 57:285-94.

Sasi Kiran K, Padmaja G. 2003. Inactivation of trypsin inhibitors in sweet potato and taro tubers during processing. Plant Foods Hum Nutr 58:153-63.

Shivaraj B, Sharma KK, Pattabiraman TN. 1979. Natural plant enzyme inhibitors: Part VII-Alpha amylase inhibitors \& amylases in plant tubers. Indian J Biochem Biophys 16: $52-5$

Walter WM, Catignani GL. 1981. Biological quality and composition of sweet potato protein fractions. J Agric Food Chem 29:797-9. 